\title{
Passivity of Co-Cr-Mo alloys in lactic acid solutions
}

\author{
A. Begić Hadžipašić*, J. Malina, T. Matković \\ Faculty of Metallurgy, University of Zagreb, Aleja narodnih heroja 3, 44103 Sisak, Croatia
}

Received 16 November 2007, received in revissed form 18 July 2008, accepted 13 April 2010

\begin{abstract}
The method of potentiodynamic polarization was used to obtain the electrochemical measurements of ten experimental Co-Cr-Mo alloys with different chemical composition in two solutions of $0.1 \%$ lactic acid (LA): medium $\mathbf{A}$ containing $\mathrm{Cl}^{-}$-ions $(0.1 \% \mathrm{LA}$ in artificial saliva, $\mathrm{pH}$ 6.52) and medium $\mathbf{B}$ without $\mathrm{Cl}^{-}$-ions (0.1\% LA in distilled water, $\mathrm{pH} 2.99$ ). These solutions as representative of oral cavity conditions were chosen in order to see if the alloys could be used in dental practice. Wironit ${ }^{\circledR}$ was used as reference material.

In vitro experiments have shown that susceptibility to local corrosion was more pronounced in solution A. In contrast, the tendency to general corrosion was greater in solution $\mathbf{B}$.

Referring to pitting potential of Wironit ${ }^{\circledR}$, samples 3 ( $\left.\mathrm{Co}_{55} \mathrm{CR}_{40} \mathrm{Mo}_{5}\right), 6\left(\mathrm{Co}_{60} \mathrm{CR}_{30} \mathrm{Mo}_{10}\right)$ and $9\left(\mathrm{Co}_{55} \mathrm{CR}_{20} \mathrm{Mo}_{25}\right)$ have shown the best performances with the highest $E_{\text {pitt }}$ value in both media. The same is valid for these three alloys if general corrosion was considered.
\end{abstract}

K e y w o r d s: Co-Cr-Mo dental alloys, passivity, lactic acid, artificial saliva, corrosion properties

\section{Introduction}

Dental alloys are exposed daily to different conditions in the oral cavity, which creates ideal conditions for corrosion $[1,2]$. The consequences of corrosion processes on dental alloys can have biological, functional and aesthetic effects. The most important among them are biological effects, because corrosion processes release metal ions that may come in contact with cells and tissues in the body and, if they are not biocompatible, they cause toxic effects in the organism [3$6]$.

In other words, materials that are used as permanent or partial prosthesis and implants in the human body, must be biocompatible, corrosion resistant, mechanically strong enough, as well as long lasting.

The most known alloys which are used today as biocompatible implant materials in stomatology are noble metal $\mathrm{Au}-\mathrm{Pt}$ alloys, $\mathrm{Ti}-$, $\mathrm{Co}$ - and Ni-based alloys. However, all of them corrode in certain conditions, so their ions may lead to different complications, such as negative reactions of tissues, infections inside the body and increased sensitivity to metals [7-9]. So, one of the goals in modern metallurgy is production of alloys with minimal tendency of corrosion and releasing of metal ions.

In opposition to noble metal alloys, dental Co-Cr alloys are not thermodynamically stable and most of their corrosion resistance aspects are connected with forming of thin protective oxide layer (passive film) on its surface [10]. If the oxide layer is broken, the bare unprotected metal corrodes depending on the aggressiveness of the medium in the oral cavity.

Since the lactic acid (LA) is common medium in the oral cavity, in this work the influence of lactic acid on the passivity of Co-Cr-Mo dental alloys with chemical composition close to that of similar commercial dental alloy was investigated. In order to compare corrosion parameters, the measurements were done in two different solutions of $0.1 \%$ lactic acid (LA): me$\operatorname{dium} \mathbf{A}$ containing $\mathrm{Cl}^{-}$-ions and medium $\mathbf{B}$ without $\mathrm{Cl}^{-}$-ions.

\section{Experimental details}

Experimental Co-Cr-Mo alloys were prepared by melting the elements in an arc furnace under argon

*Corresponding author: tel.: +385 33533 379; e-mail address: anitabegic@yahoo.ca 
Ta b l e 1. Chemical composition of artificial saliva (against AFNOR standard S90-701)

\begin{tabular}{lc}
\hline Chemical compound & Composition $\left(\mathrm{g} \mathrm{l}^{-1}\right)$ \\
\hline $\mathrm{Na}_{2} \mathrm{HPO}_{4}$ & 0.260 \\
$\mathrm{NaCl}$ & 6.700 \\
$\mathrm{KSCN}$ & 0.330 \\
$\mathrm{KH}_{2} \mathrm{PO}_{4}$ & 0.200 \\
$\mathrm{NaHCO}_{3}$ & 1.500 \\
$\mathrm{KCl}$ & 1.200 \\
\hline
\end{tabular}

atmosphere. Casting of alloys was realized thanks to specially constructed copper anode, which was used also as casting mould. As-cast alloys were submitted to heat treatment in order to achieve microstructural homogenisation. It included two hours of heating in a quartz tube filled with argon at $950^{\circ} \mathrm{C}$ and cooling in air to the room temperature.

Ten Co-Cr-Mo alloys were examined in which the content of Co varied between 55 and 90 at.\%, so that Co presents a metal matrix, while the contents of $\mathrm{Cr}$ and Mo varied in range of 5-40 at.\%. In addition to the experimental Co-Cr-Mo alloys, commercial Co-Cr-Mo alloy Wironit ${ }^{\circledR}$ (Bego, Bremen, Germany) was used in order to compare the results of corrosion experiments. As well as cobalt (64 at.\%), chromium (28 at.\%) and molybdenum (5 at.\%), Wironit ${ }^{\circledR}$ also contains carbon $(0.35$ at.\%), silicon and manganese (1.35 at.\%) in its chemical composition.

Electrochemical measurements were performed with electrodes made of metal cylindrical samples fixed with two-component epoxy resin inside the glass tube. Prior to electrochemical measurements the surface of the working electrode was mechanically grinded with $\mathrm{SiC}$ paper (400-600 grit) and subsequently flushed with distilled water and degreased in ethanol.

In order to compare corrosion parameters, in vitro measurements were done in two LA solutions. Artificial saliva with $0.1 \% \mathrm{LA}$ added (medium $\mathbf{A}, \mathrm{pH}=$ 6.52 ) was compared to the $0.1 \% \mathrm{LA}$ (medium $\mathbf{B}, \mathrm{pH}$ $=2.99)$. The chemical composition of artificial saliva is shown in Table 1.

During the experiment the working medium was aerated (flow rate $30 \mathrm{~L} \mathrm{~h}^{-1}$ ) at controlled temperature of $37 \pm 0.5^{\circ} \mathrm{C}$.

By the laboratory potentiostat Wenking 68FR0.5 the next potentiodynamic measurements were performed [10]:

a) potentiodynamic polarization in a close range of potential going from $-300 \mathrm{mV}$ to $200 \mathrm{mV}$ vs. $E_{\text {corr }}$, while scanning rate $\mathrm{d} E / \mathrm{d} t$ was $1 \mathrm{mV} \mathrm{s}^{-1}$;

b) cyclic anodic polarization going from $E_{\text {corr }}$ to $1200 \mathrm{mV}$ vs. SCE (saturated calomel electrode) and reverse, while scanning rate $\mathrm{d} E / \mathrm{d} t$ was $2 \mathrm{mV} \mathrm{s}^{-1}$.

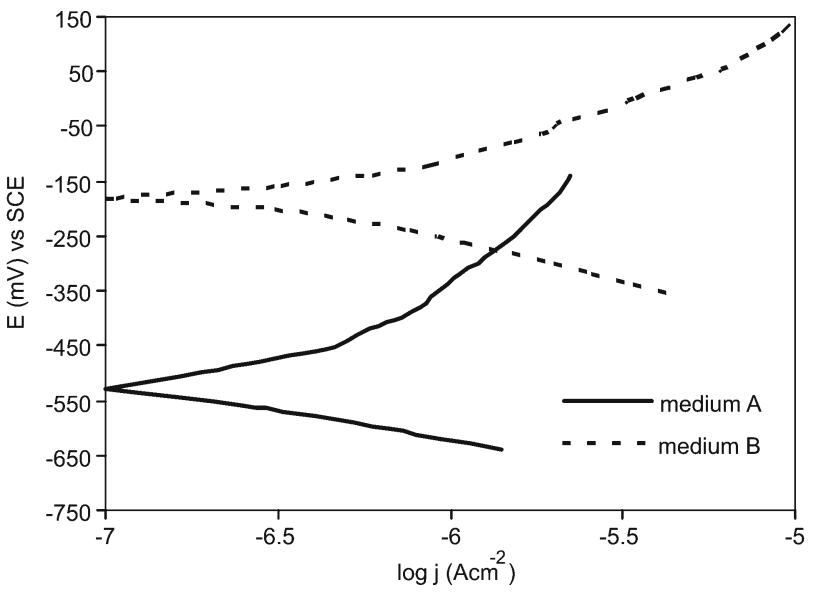

Fig. 1. E-log $j$ diagram for sample $9\left(\mathrm{Co}_{55} \mathrm{Cr}_{20} \mathrm{Mo}_{25}\right)$.

Metallographic analyses were performed in order to investigate the influence of microstructure on the corrosion properties of examined alloys. Samples for metallography were mechanically grinded (with 120 600 grit $\mathrm{SiC}$ paper) and finally polished with $\mathrm{Al}_{2} \mathrm{O}_{3}$ water suspension. Etching was accomplished with solution of $10 \mathrm{~g} \mathrm{~K}_{3} \mathrm{Fe}(\mathrm{CN})_{6}$ and $10 \mathrm{~g} \mathrm{KOH}$ in $100 \mathrm{~cm}^{3}$ $\mathrm{H}_{2} \mathrm{O}$ warmed on $100{ }^{\circ} \mathrm{C}$. The etched samples were observed by optical microscope Leitz Ortholux. The metallographic photographs taken with digital camera (Olympus, type DP 11) were analysed with corresponding programmes (Olympus DP-Soft, UTHSCA Image Tool).

\section{Results}

Potentiodynamic polarization in a close range of potential [11] was done in order to determine characteristic parameters of general corrosion from polarization curves, i.e. corrosion potential $E_{\text {corr }}$, corrosion current density $j_{\text {corr }}$ and Tafel's constants. The values obtained are presented in Table 2. E-log $j$ diagram for sample 9 is shown in Fig. 1 (the other samples have shown similar characteristics).

Cyclic anodic potentiodynamic polarization was performed with the aim to determine characteristic parameters of local corrosion from experimental polarization curves, i.e. pitting potential $E_{\text {pitt }}$, repassivating potential $E_{\text {rep }}$ and hysteresis potential $E_{\text {hys }}[10]$.

The corrosion resistance of alloys can be evaluated on the base of pitting potential, so that the greater $E_{\text {pitt }}$ value the better corrosion resistance is. In this work $E_{\text {pitt }}$ values were determined according to the criterion of extreme increase of current on anodic polarization curves (Figs. 2 and 3). For the comparison purpose, $E_{\text {pitt }}$ value of Wironit ${ }^{\circledR}$ was used as reference value. The characteristic $E$-values determined from the cyclic anodic polarization curves are shown in Table 3. 
Table 2. The parameters of general corrosion for Co-Cr-Mo alloys in LA solutions

\begin{tabular}{|c|c|c|c|c|c|c|c|c|c|}
\hline \multirow{2}{*}{$\begin{array}{l}\text { Sample } \\
\text { no. }\end{array}$} & \multirow{2}{*}{$\begin{array}{l}\text { Alloy composition } \\
\quad \text { (at.\%) }\end{array}$} & \multicolumn{4}{|c|}{ Medium $\mathbf{A}(\mathrm{pH}=6.52)$} & \multicolumn{4}{|c|}{ Medium $\mathbf{B}(\mathrm{pH}=2.99)$} \\
\hline & & $\begin{array}{l}E_{\text {corr }} \\
(\mathrm{mV})\end{array}$ & $\left(\begin{array}{c}j_{\mathrm{corr}} \\
\mathrm{cm}^{-2}\end{array}\right)$ & $\begin{array}{c}b_{\mathrm{a}} \\
(\mathrm{mV})\end{array}$ & $\begin{array}{c}b_{\mathrm{c}} \\
(\mathrm{mV})\end{array}$ & $\begin{array}{l}E_{\text {corr }} \\
(\mathrm{mV})\end{array}$ & $\left(\begin{array}{c}j_{\mathrm{corr}} \\
\mathrm{cm}^{-2}\end{array}\right)$ & $\begin{array}{c}b_{\mathrm{a}} \\
(\mathrm{mV})\end{array}$ & $\begin{array}{c}b_{\mathrm{c}} \\
(\mathrm{mV})\end{array}$ \\
\hline 1 & $\mathrm{Co}_{75} \mathrm{Cr}_{12.5} \mathrm{Mo}_{12.5}$ & -350 & $2.82 \times 10^{-7}$ & 500 & 182 & -170 & $1.78 \times 10^{-6}$ & 286 & 222 \\
\hline 2 & $\mathrm{Co}_{55} \mathrm{Cr}_{5} \mathrm{Mo}_{40}$ & -580 & $2.34 \times 10^{-7}$ & 222 & 133 & -170 & $1.58 \times 10^{-6}$ & 133 & 200 \\
\hline 3 & $\mathrm{Co}_{55} \mathrm{Cr}_{40} \mathrm{Mo}_{5}$ & -380 & $1.64 \times 10^{-7}$ & 500 & 167 & -125 & $3.39 \times 10^{-7}$ & 333 & 222 \\
\hline 4 & $\mathrm{Co}_{90} \mathrm{Cr}_{5} \mathrm{Mo}_{5}$ & -500 & $4.12 \times 10^{-7}$ & 250 & 154 & -280 & $5.75 \times 10^{-5}$ & 143 & 182 \\
\hline 5 & $\mathrm{Co}_{80} \mathrm{Cr}_{10} \mathrm{Mo}_{10}$ & -630 & $1.95 \times 10^{-7}$ & 500 & 111 & -245 & $1.51 \times 10^{-6}$ & 182 & 222 \\
\hline 6 & $\mathrm{Co}_{60} \mathrm{Cr}_{30} \mathrm{Mo}_{10}$ & -330 & $1.82 \times 10^{-7}$ & 500 & 200 & -70 & $6.31 \times 10^{-7}$ & 333 & 222 \\
\hline 7 & $\mathrm{Co}_{60} \mathrm{Cr}_{10} \mathrm{Mo}_{30}$ & -520 & $3.55 \times 10^{-7}$ & 400 & 167 & -190 & $1.90 \times 10^{-6}$ & 167 & 200 \\
\hline 8 & $\mathrm{Co}_{75} \mathrm{Cr}_{5} \mathrm{Mo}_{20}$ & -480 & $3.89 \times 10^{-7}$ & 333 & 167 & -240 & $7.94 \times 10^{-6}$ & 143 & 200 \\
\hline 9 & $\mathrm{Co}_{55} \mathrm{Cr}_{20} \mathrm{Mo}_{25}$ & -530 & $1.78 \times 10^{-7}$ & 500 & 222 & -180 & $4.27 \times 10^{-7}$ & 333 & 167 \\
\hline 10 & $\mathrm{Co}_{75} \mathrm{Cr}_{20} \mathrm{Mo}_{5}$ & -390 & $1.91 \times 10^{-7}$ & 500 & 200 & -225 & $7.29 \times 10^{-7}$ & 286 & 222 \\
\hline 11 & WIRONIT $^{\circledR}$ & -500 & $1.41 \times 10^{-7}$ & 500 & 200 & -130 & $2.00 \times 10^{-7}$ & 286 & 250 \\
\hline
\end{tabular}

Table 3. The parameters of local corrosion for Co-Cr-Mo alloys in LA solutions

\begin{tabular}{|c|c|c|c|c|c|c|c|c|c|}
\hline \multirow{2}{*}{$\begin{array}{l}\text { Sample } \\
\text { no. }\end{array}$} & \multirow{2}{*}{$\begin{array}{l}\text { Alloy composition } \\
(\text { at. } \%)\end{array}$} & \multicolumn{4}{|c|}{ Medium $\mathbf{A}(\mathrm{pH}=6.52)$} & \multicolumn{4}{|c|}{ Medium B $(\mathrm{pH}=2.99)$} \\
\hline & & $\begin{array}{l}E_{\text {corr }} \\
(\mathrm{mV})\end{array}$ & $\begin{array}{l}E_{\text {pitt }} \\
(\mathrm{mV})\end{array}$ & $\begin{array}{l}E_{\mathrm{rep}} \\
(\mathrm{mV})\end{array}$ & $\begin{array}{l}E_{\text {hys }} \\
(\mathrm{mV})\end{array}$ & $\begin{array}{l}E_{\text {corr }} \\
(\mathrm{mV})\end{array}$ & $\begin{array}{l}E_{\mathrm{pitt}} \\
(\mathrm{mV})\end{array}$ & $\begin{array}{l}E_{\mathrm{rep}} \\
(\mathrm{mV})\end{array}$ & $\begin{array}{l}E_{\mathrm{hys}} \\
(\mathrm{mV})\end{array}$ \\
\hline 1 & $\mathrm{Co}_{75} \mathrm{Cr}_{12.5} \mathrm{Mo}_{12.5}$ & -350 & 875 & 260 & 615 & -170 & 983 & $\sim 983$ & - \\
\hline 2 & $\mathrm{Co}_{55} \mathrm{Cr}_{5} \mathrm{Mo}_{40}$ & -580 & 50 & 20 & 30 & -170 & 273 & $\sim 273$ & - \\
\hline 3 & $\mathrm{Co}_{55} \mathrm{Cr}_{40} \mathrm{Mo}_{5}$ & -380 & 905 & 662 & 243 & -125 & 1080 & $\sim 1080$ & - \\
\hline 4 & $\mathrm{Co}_{90} \mathrm{Cr}_{5} \mathrm{Mo}_{5}$ & -500 & -30 & -385 & 355 & -280 & 30 & $\sim 30$ & - \\
\hline 5 & $\mathrm{Co}_{80} \mathrm{Cr}_{10} \mathrm{Mo}_{10}$ & -630 & 625 & -135 & 760 & -245 & 760 & $\sim 760$ & - \\
\hline 6 & $\mathrm{Co}_{60} \mathrm{Cr}_{30} \mathrm{Mo}_{10}$ & -330 & 958 & 543 & 415 & -70 & 1100 & $\sim 1100$ & - \\
\hline 7 & $\mathrm{Co}_{60} \mathrm{Cr}_{10} \mathrm{Mo}_{30}$ & -520 & 245 & -395 & 640 & -190 & 560 & $\sim 560$ & - \\
\hline 8 & $\mathrm{Co}_{75} \mathrm{Cr}_{5} \mathrm{Mo}_{20}$ & -480 & 75 & 30 & 45 & -240 & 285 & $\sim 285$ & - \\
\hline 9 & $\mathrm{Co}_{55} \mathrm{Cr}_{20} \mathrm{Mo}_{25}$ & -530 & 1010 & 970 & 40 & -180 & 1130 & $\sim 1130$ & - \\
\hline 10 & $\mathrm{Co}_{75} \mathrm{Cr}_{20} \mathrm{Mo}_{5}$ & -390 & 890 & -50 & 940 & -225 & 1020 & $\sim 1020$ & - \\
\hline 11 & WIRONIT $^{\circledR}$ & -500 & 900 & 380 & 520 & -130 & 1060 & $\sim 1060$ & - \\
\hline
\end{tabular}

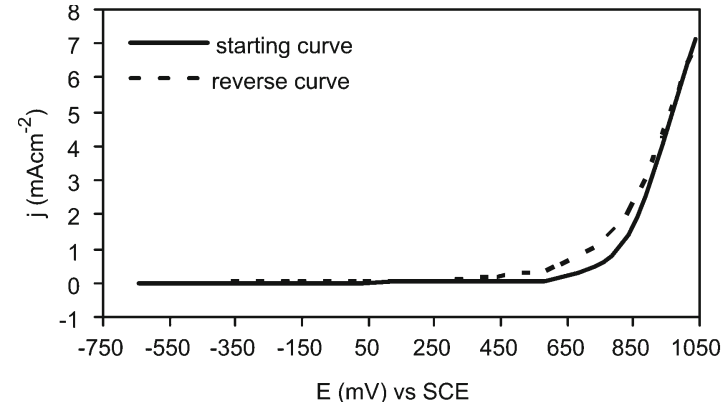

Fig. 2. The cyclic voltammogram for sample $9\left(\mathrm{Co}_{55} \mathrm{Cr}_{20}-\right.$ $\left.\mathrm{Mo}_{25}\right)$ in the medium $\mathbf{A}$.

Microstructural characteristics of examined alloys strongly depend on chemical composition, as it can be seen from the microstructure of alloy $3\left(\mathrm{Co}_{55} \mathrm{Cr}_{40} \mathrm{Mo}_{5}\right)$ in Fig. 4 and alloy $9\left(\mathrm{Co}_{55} \mathrm{Cr}_{20} \mathrm{Mo}_{25}\right)$ in Fig. 5.

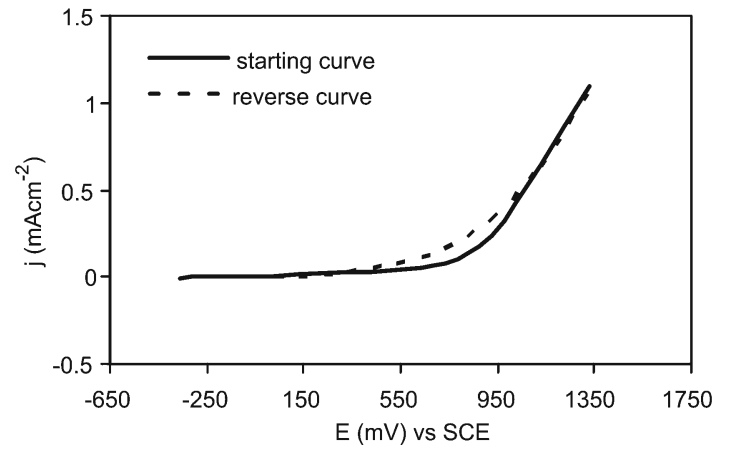

Fig. 3. The cyclic voltammogram for sample $9\left(\mathrm{Co}_{55} \mathrm{Cr}_{20^{-}}\right.$ $\mathrm{Mo}_{25}$ ) in the medium $\mathbf{B}$.

\section{Discussion}

On the basis of results in Table 2 it can be seen that for all examined alloys $E_{\text {corr }}$ values were much 


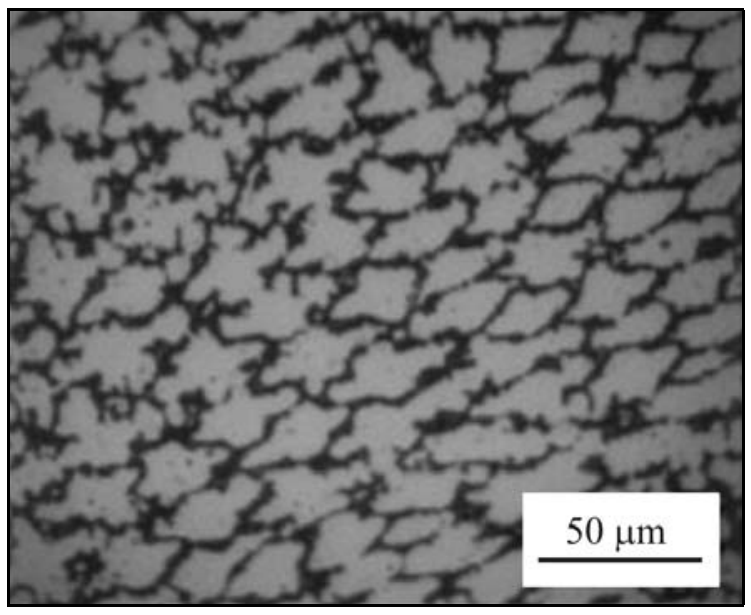

Fig. 4. Microstructure of sample $3\left(\mathrm{Co}_{55} \mathrm{Cr}_{40} \mathrm{Mo5}_{5}\right)$.

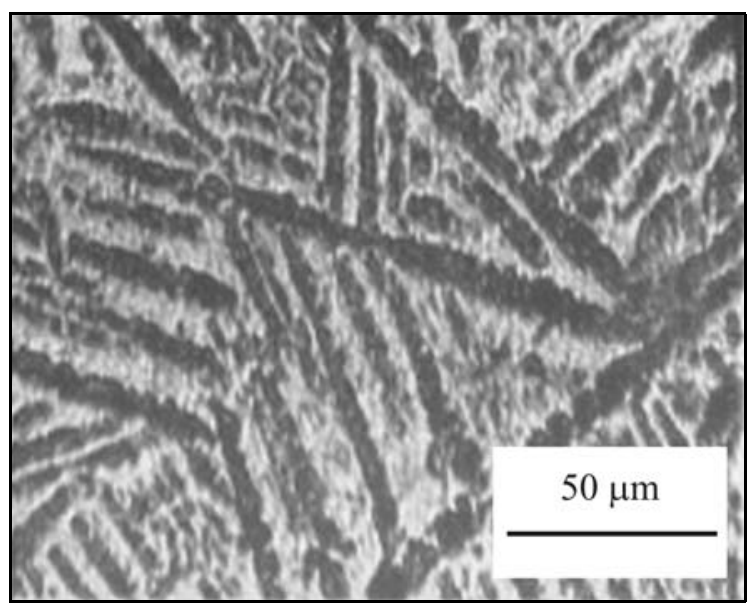

Fig. 5. Microstructure of sample $9\left(\mathrm{Co}_{55} \mathrm{Cr}_{20} \mathrm{Mo}_{25}\right)$.

more positive in the medium B. For instance, sample 9 has a value of $E_{\text {corr }}=-180 \mathrm{mV}$ (vs. SCE) in solution $\mathbf{B}$, while in solution $\mathbf{A}, E_{\text {corr }}=-530 \mathrm{mV}$ (vs. SCE) (Fig. 1).

Also, it can be seen from Table 2 that values of $j_{\text {corr }}$ in the medium $\mathbf{A}$ are lower than those in the medium B. For instance, the $j_{\text {corr }}$ values of samples 3 , 6 and 9 are especially low and they are in the range from $1.64 \times 10^{-7}$ to $1.82 \times 10^{-7} \mathrm{~A} \mathrm{~cm}^{-2}$, while the other samples are characterized with $j_{\text {corr }}$ ranging from $1.91 \times 10^{-7}$ to $4.12 \times 10^{-7} \mathrm{~A} \mathrm{~cm}^{-2}$. Wironit ${ }^{\circledR}$ has the lowest $j_{\text {corr }}$ value of $1.41 \times 10^{-7} \mathrm{~A} \mathrm{~cm}^{-2}$.

The same can be concluded for dental alloys in the medium $\mathbf{B}$, although it is important to emphasize that the values of $j_{\text {corr }}$ in the medium $\mathbf{B}$ are higher then those in $\mathbf{A}$. It means that an increased acidity of the solution $\mathbf{B}$ has a dominant role in the general corrosion of examined Co-Cr-Mo alloys.

The sample $4\left(\mathrm{Co}_{90} \mathrm{Cr}_{5} \mathrm{Mo}_{5}\right)$ has shown the lowest corrosion resistance in both media, while commercial product Wironit ${ }^{\circledR}$ has shown the best performance.

The highest values of anodic and cathodic slope were obtained for alloys, which have shown the best corrosion resistance, i.e. the lowest values of corrosion current density. Higher $b_{\mathrm{a}}$ and $b_{\mathrm{c}}$ indicate the existence of especially stable passive layer, which protects dental prosthesis from the medium in the oral cavity. However, as local corrosion processes result in the breakdown of such passive layer, it is important to obtain the pitting resistance from the anodic polarization. Cyclic polarization curves in the medium $\mathbf{A}$ differ from those in $\mathbf{B}$, as it can be seen in Figs. 2 and 3 for sample 9 . $E_{\text {pitt }}$ values as well as $E_{\text {rep }}$ values determined in the medium $\mathbf{B}$ are higher then those in the medium A (Table 3).

Referring to pitting potential of Wironit ${ }^{\circledR}\left(E_{\text {pitt }}\right.$ $=900 \mathrm{mV}$ ), it can be seen from Table 3 that in the medium A only samples 3, 6 and 9 have higher pitting potential. $E_{\text {pitt }}$ values for these samples are in the range from $905 \mathrm{mV}$ to $1010 \mathrm{mV}$, while the other samples are characterized with $E_{\text {pitt }}$ ranging from $-30 \mathrm{mV}$ to $890 \mathrm{mV}$. The sample 4 has shown the lowest corrosion resistance with the value of $E_{\text {pitt }}=-30 \mathrm{mV}$. The same ranking has also been shown in solution $\mathbf{B}$, where $E_{\text {pitt }}$ values for samples 3,6 and 9 are in the range from $1080 \mathrm{mV}$ to $1130 \mathrm{mV}$, which is again higher than pitting potential of Wironit ${ }^{\circledR}\left(E_{\text {pitt }}=1060 \mathrm{mV}\right)$.

All the results obtained in two different media containing $0.1 \%$ LA suggest that the passivation ability of investigated alloys is governed by the presence of $\mathrm{Cl}^{-}$-ions in artificial saliva. However, the noticed difference in electrochemical behaviour of examined alloys can be found in their chemical composition [1214]. It is known that chromium improves chemical stability of the alloy and its stability in the mouth. It also increases corrosion resistance, what is shown in this work. Namely, samples 3, 6, 9 and commercial Wironit ${ }^{\circledR}$ with highest amount of chromium have shown the least tendency to corrosion, because they had the lowest $j_{\text {corr }}$ values and the highest pitting potential values.

The factors of corrosion resistance can also be found in the microstructure of examined alloys [15]. According to metallographic micrograph, it can be seen that sample 3, which has shown a good corrosion resistance, has typical dendritic solidification two phases microstructure (Fig. 4). It consists of dendrites (light) and interdendritic region (dark), with two types of Co-Cr-Mo solid solutions, which differ in structure [16]. A "light" phase has fcc-structure and etched difficulty, as a nobler phase. On the contrary, a "dark" phase etched easier, as a less noble phase that has hcp-structure [17, 18]. All samples with similar chemical composition have this type of microstructure, which is typical for commercial dental alloys. However, alloy 9 has also shown a good corrosion resistance, but 
its microstructure differs slightly (Fig. 5) from that of sample 3 which can be ascribed to the difference in the chemical composition of darker and lighter phase [17] and to the bigger difference of potentials between these two phases [16]. Also, such chemical behaviour of examined alloys can be connected to the content of constituents ( $\mathrm{Co}, \mathrm{Cr}, \mathrm{Mo})$ from which each has its own electrochemical behaviour [19]. Electrochemical behaviour, composition and solubility of the surface layers, formed on the individual metal components, Co and $\mathrm{Cr}$, in neutral and alkaline solution have been relatively well studied [20-25]. However, synergic activity of electrochemical behaviours of these three components differs from their individual behaviour [26-28].

\section{Conclusion}

The corrosion parameters of ten experimental CoCr-Mo alloys were determined by the method of potentiodynamic polarization in two solutions of $0.1 \%$ lactic acid (medium $\mathbf{A}$ containing $\mathrm{Cl}^{-}$-ions and medium $\mathbf{B}$ without $\mathrm{Cl}^{-}$-ions) and compared with the relevant indicators of commercial dental alloy Wironit ${ }^{\circledR}$. On the basis of investigations performed it can be concluded:

1. In vitro experiments have shown that the susceptibility to passivity breakdown was more pronounced in solution A. In contrast, the tendency to general corrosion was greater in solution $\mathbf{B}$. It means that an increased acidity of the solution $\mathbf{B}$ does not have a dominant role in the passivity of examined Co-Cr-Mo alloys.

2 . The corrosion resistance of alloys was evaluated on the base of pitting potential, so that the greater $E_{\text {pitt }}$ value means the better corrosion resistance.

3. Referring to pitting potential of Wironit ${ }^{\circledR}$, only alloys $3\left(\mathrm{Co}_{55} \mathrm{Cr}_{40} \mathrm{Mo}_{5}\right), 6\left(\mathrm{Co}_{60} \mathrm{Cr}_{30} \mathrm{Mo}_{10}\right)$ and 9 $\left(\mathrm{Co}_{55} \mathrm{Cr}_{20} \mathrm{Mo}_{25}\right)$ have higher pitting potential in both solutions, while the sample $4\left(\mathrm{Co}_{90} \mathrm{Cr}_{5} \mathrm{Mo}_{5}\right)$ has shown the lowest pitting resistance.

4. A good corrosion resistance of samples $3,6,9$ and Wironit ${ }^{\circledR}$ can be attributed not only to increased content of chromium, but also to their microstructure.

5 . The samples with highest corrosion resistance have typically eutectic dendrite microstructure characteristic for commercial Co-Cr dental alloys, so this insight should make creation of new biomedically acceptable materials possible.

\section{Acknowledgement}

This work was supported by the Ministry of Science, Education and Sports of the Republic of Croatia within the project 124-1241565-1524.

\section{References}

[1] POLJAK-GUBERINA, R.-KNEZOVIĆ-ZLATARIĆ, D.-KATUNARIĆ, M.: Acta Stomatol. Croat., 36,2002 , p. 441.

[2] RINČIĆ, N.-ČELEBIĆ, A.-BAUČIĆ, I.-STIPETIĆ, J.-PROHIĆ, E.-MIKO, S.: Acta Stomatol. Croat., 37, 2003, p. 5.

[3] CORTADA, M.-GINER, L. L.-COSTA, S.-GIL, F. J.-RODRIGUEZ, D. - PLANELL, J. A.: J. Mater. Sci. Mater. in Med., 11, 2000, p. 287. doi:10.1023/A:1008905229522

[4] WATAHA, J. C.—CRAIG, R. G.-HANKS, C. T.: J. Dent. Res., 70, 1991, p. 1014.

[5] HENNING, F. F.-RAITHEL, H. J.-SCHALLER, K. H.-DOHLER, J. R.: J. Trace Elem. Electrolyte Health Dis., 6, 1992, p. 239.

[6] SUN, Z. L.-WATAHA, J. C.-HANKS, C. T.: J. Biomed. Mater. Res., 34, 1997, p. 29. doi:10.1002/(SICI) 1097-4636(199701)34:1<29::AIDJBM5 > 3.0.CO;2-P

[7] GRANCHI, D.-CENNI, E.-CIAPETTI, G.-SAVARINO, L.-STEA, S.-GAMBERINI, G.-GORI, A.-PIZZOFERRATO, A.: J. Mater. Sci. Mater. in Med., 9, 1998, p. 31. doi:10.1023/A:1008878527233

[8] SILVA, R. A.-BARBOSA, M. A.-VILAR, R.CONDE, O.-DA CUNHA BELO, M.-SUTHERLAND, I.: J. Mater. Sci. Mater. in Med., 5, 1994, p. 353. doi:10.1007/BF00058962

[9] BETTS, B.-WRIGHT, T.-SALVATI, E. A.-BOSKEY, A.-BANSAL, M.: Clinical Orthopaedics and Related Research, 272, 1990, p. 75.

[10] BEGIĆ, A.-MALinA, J.-MATKOVIĆ, P.: Acta Stomatol Croat., 37, 2003, p. 251.

[11] ASTM G3-89 (2004): Standard Practice for Conventions Applicable to Electrochemical Measurements in Corrosion Testing.

[12] MALina, J.-MATKOViĆ, T.-MATKOViĆ, P.: In: Zbornik referatov 38. livarskog posvetovanja $\mathrm{s}$ sodelovanjem drzav heksagonale. Eds.: Trbižan, M. Portorož, Društvo livarjev Slovenije 1997, p. 196.

[13] VANDAMME, N. S.-WAYMAN, B. H.-TOPOLESKI, L. D. T.: J. Mater. Sci. Mater. in Med., 14, 2003, p. 47. doi:10.1023/A:1021549403641

[14] GRKOVIĆ, B.-TEODOSIJEVIĆ, M.: Dental Materials. Belgrade, Institute for Textbook Publishing and Teaching Aids 1989 (in Croatian).

[15] Begić, A.-MALinA, J.-MATKOViĆ, T.: Metalurgija, 43, 2004, p. 63.

[16] MATKOVIĆ, T.-MATKOVIĆ, P.-MALINA, J.: J. Alloys and Compounds, 366, 2004, p. 293.

[17] MATKOVIĆ, P.-MATKOVIĆ, T.-MALINA, J.: Metalurgija, 37, 1998, p. 15.

[18] MONTERO-OCAMPO, C.-JUAREZ, R.-SALINAS-RODRIGUEZ, A.: Metall. Trans. A, 33A, 2002, p. 2229. doi:10.1007/s11661-002-0054-0

[19] POURBAIX, M.: Atlas of Electrochemical Equilibria in Aqueous Solutions. London, Pergamon Press 1996.

[20] GOMEZ MEIER, H.-VILCHE, J. R.-ARVIA, A. J.: J. Electroanal. Chem., 134, 1982, p. 367.

[21] BADAWY, W. A.-AL-KHARAFI, F. M. - ALAJMI, J. R.: J. Appl. Electrochem., 30, 2000, p. 693. $\underline{\text { doi:10.1023/A:1003893122201 }}$ 
[22] ISMAIL, K. M.-ADAWY, W. A.: J. Appl. Electrochem., 30, 2000, p. 1303.

doi:10.1023/A:1026560422090

[23] FOELSKE, A.-STREHBLOW, H.-H.: Surf. Interface Anal., 29, 2000, p. 548.

doi:10.1002/1096-9918(200008)29:8<548::AID-SIA902 $>3.0 . \mathrm{CO} ; 2-\mathrm{Q}$

[24] FOELSKE, A.-STREHBLOW, H.-H.: Surf. Interface Anal., 34, 2002, p. 125. doi:10.1002/sia.1267
[25] METIKOŠ-HUKOVIĆ, M.-CERAJ-CERIĆ, M.: J. Electrochem. Soc., 134, 1987, 2193.

[26] METIKOŠ-HUKOVIĆ, M.-BABIĆ, R.-OMANOVIĆ, D.-MILOŠEV, I.: ECS Transactions, 2, 2007, p. 43.

[27] MILOŠEV, I.-STREHBLOW, H.-H.: Electrochimica Acta, 48, 2003, p. 2767.

[28] GIACOMELLI, F. C.-GIACOMELLI, C.-SPINELLI, A.: J. Braz. Chem. Soc., 15, 2004, p. 541. 